\title{
Differential gene expression in primary colonic tissue from control, FAP and AFAP patients reveals unique signatures with diagnostic potential
}

\author{
Deborah W Neklason*, Brett A Milash, Therese M Tuohy, Jennifer Lilley, Randall W Burt \\ From 13th Annual Meeting of the Collaborative Group of the Americas on Inherited Colorectal Cancer \\ Honolulu, Hawaii, USA. 16-17 October 2009
}

\section{Background}

Familial adenomatous polyposis (FAP) is a colon cancer syndrome with a prevalence of 1:10,000. Patients have 100 's to 1000's of precancerous colonic polyps and nearly $100 \%$ risk of developing colon cancer at an average age of 39 years in the absence of colon surveillance and surgery. Mutations in the APC gene lead to FAP as well as an attenuated form (AFAP) which presents with variable phenotypic expression, reduced polyp numbers and reduced cancer risk as compared to FAP. Current methods for the clinical diagnosis of genetic diseases most commonly involve analysis of germline DNA. Germline DNA-based diagnosis can be incomplete, for example no mutation is found in approximately $20 \%$ of FAP and $50 \%$ of AFAP patients. The objective of this study is to determine a molecular profile of the colonic epithelia from patients with APC mutations leading to FAP or AFAP then to use this information to establish a gene expression signature for diagnosis and for better understanding of the disease in the primary affected tissue.

\section{Methods}

Fresh normal-appearing colonic epithelia were obtained as biopsies during endoscopy and immediately placed in RNA-later, a tissue preservative for RNA integrity. RNA was extracted using Qiagen RNeasy purification system. Aglient 44K RNA microarrays were run using mRNA from FAP patients $(\mathrm{n}=6)$, AFAP patients $(\mathrm{n}=14)$ and control patients $(n=12)$. Normalized log ratios for each

* Correspondence: deb.neklason@hci.utah.edu

2000 Circle of Hope, Huntsman Cancer Institute, University of Utah, Salt Lake City, Utah 84112-5550, USA sample vs. reference RNA were the input for analysis using the Rank Product to generate a p-value for significance of differential expression and to cluster using Ward's Method in the Spotire DecisionSite software.

\section{Results}

Analysis using the Rank Product method found 48 mRNA probes with statistical significance $(\mathrm{p}<0.001)$ that consistently distinguish between control, FAP and AFAP normal appearing colonic tissue. These probes are up in FAP vs. control but low in AFAP vs. control or vice versa and will be tested for their accuracy to classify FAP and AFAP patients. Differential expression was also evaluated to better understand the phenotypic variability within AFAP using 5 individuals with $>100$ adenomas versus 6 individuals with $<20$ adenomas with the identical APC mutation. Differential expression identified 245 probes with a p-value of $<0.05$. The most striking were DEFA5 and DEFA6, encoding microbicidal defensins involved in host defense, which consistently showed increased expression in the $>100$ adenoma group. It is not clear if this reflects a host or an environmental difference and will require further study.

\section{Conclusions}

In conclusion, a distinct gene expression signature can be identified in FAP vs. AFAP patients that, in turn, can be applied to diagnostics. A separate set of genes can also distinguish colonic phenotypic classes of individuals with the identical APC mutation and may suggest secondary factors that modify the phenotypic penetrance in AFAP. 


\section{Acknowledgement}

This research was funded by NIH grants ROI-CA040641 (RWB) and P01-

CA07392 and Huntsman Cancer Foundation.

Published: 25 May 2010

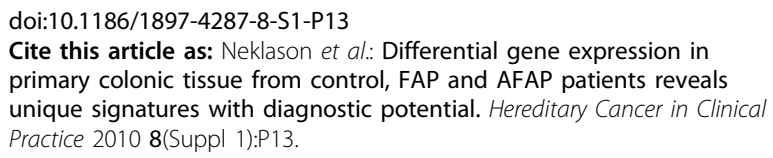

Submit your next manuscript to BioMed Central and take full advantage of:

- Convenient online submission

- Thorough peer review

- No space constraints or color figure charges

- Immediate publication on acceptance

- Inclusion in PubMed, CAS, Scopus and Google Scholar

- Research which is freely available for redistribution

Submit your manuscript at www.biomedcentral.com/submit

() Biomed Central 